\title{
Alimento fermentado elaborado con semillas de Canavalia ensiformis sobre el crecimiento y la canal de corderos Pelibuey
}

\author{
Fermented feed elaborated with seeds of Canavalia \\ ensiformis on growth and carcass of Pelibuey lambs
}

\author{
Wilber Hernández-Montiela, J esús Alberto Ramos-J uáreza , Emilio Manuel Aranda-l báñeza \\ Omar Hernández-Mendob, Víctor Manuel Munguía-Floresc, J orge Oliva-Hernándezd
}

\begin{abstract}
RESUMEN
El objetivo de este estudio fue determinar la influencia de un alimento fermentado, elaborado con semillas de Canavalia ensiformis, sobre el comportamiento productivo y características de la canal de ovinos Pelibuey ( $\mathrm{n}=\mathbf{1 8}$ ). El diseño utilizado fue completamente al azar con dos factores con medidas repetidas en un factor. Los factores fueron tipo de dieta [alimento sin fermentar con canavalia (SFC), alimento fermentado con canavalia (FC), alimento sin fermentar y sin canavalia (SFSC)] y número de periodo de evaluación. Se evaluó peso vivo (PV), ganancia diaria de peso (GDP), consumo diario de materia seca, proteína cruda y energía metabolizable, así como peso y rendimiento de la canal. El tipo de dieta, número de período y la interacción tipo de dieta $x$ número de período afectaron $(\mathrm{P}<\mathbf{0 . 0 1})$ el consumo de todos los nutrimentos estudiados, PV y GDP. El tipo de dieta afectó $(P<0.01)$ el peso de la canal. La dieta FC permitió una mayor GDP $(P<0.01)$ con respecto a la dieta SFC. Los ovinos alimentados con la dieta SFSC fueron los que mostraron la mayor GDP $(P<0.05)$. En conclusión, la alimentación de ovinos con dietas con harina de semillas de canavalia permitió cambios positivos en el crecimiento y peso de la canal. Sin embargo, estos cambios fueron de menor magnitud con respecto a los obtenidos con una dieta sin semillas de canavalia.
\end{abstract}

PALABRAS CLAVE: Finalización, Ganancia diaria de peso, Leguminosa, Trópico húmedo.

\begin{abstract}
The aim of this study was to determine the influence of a fermented food, made with Canavalia ensiformis seeds on growth performance and carcass characteristics of Pelibuey lambs $(n=18)$. A completely randomized design with twofactor and repeated measures on a factor was used. The factors were the type of diet [unfermented food with canavalia (UFC), fermented food with canavalia (FC) and unfermented food without canavalia (UFWC)] and number of evaluation period. The variables evaluated were body weight (BW), average daily weight gain (ADG), average daily intake of dry matter, crude protein and metabolizable energy, as well as weight carcass and carcass yield. Type of diet, period number and type of diet $x$ period number interaction affected $(P<0.01)$ intake of all nutrients studied, BW and ADG. Type of diet affected $(P<0.01)$ carcass weight. The FC diet allowed greater ADG $(P<0.01)$ compared to UFC diet. Lambs fed with a diet UFWC had the highest ADG $(P<0.05)$. In conclusion, lambs feeding diets containing canavalia seed meal allowed positive changes in growth and carcass weight; however, these changes were smaller in magnitude compared to those obtained with a diet without canavalia.
\end{abstract}

KEY WORDS: Fattening, Daily weight gain, Legume, Humid tropic.

Recibido el 27 de febrero de 2015. Aceptado el 14 de abril de 2015.

a Colegio de Postgraduados, Campus Tabasco, 86500 Cárdenas, Tabasco, México.

b Colegio de Postgraduados, Campus Montecillo, 56230 Montecillo, Estado de México, México.

Práctica privada, Jalapa, Tabasco, México.

d Instituto Nacional de Investigaciones Forestales, Agrícolas y Pecuarias, 86400 Huimanguillo, Tabasco, México. olivajh20@yahoo.com.mx. Correspondencia al último autor. 
En la elaboración de alimentos para ovinos se emplean diversos ingredientes, destacando aquéllos que aportan energía y proteína, debido a que este tipo de ingredientes pueden tener un alto valor económico por sí mismos, o porque tienen una importante participación porcentual en la composición de la dieta.

En el caso específico de los ingredientes proteínicos de origen vegetal, la región tropical de México posee condiciones edáficas y climáticas que permiten el desarrollo de leguminosas tropicales, las cuales producen semillas con un alto potencial para ser incorporadas en la dieta de los ovinos. Sin embargo, este tipo de semillas requieren de investigación complementaria a la ya existente(1-6), con el fin de facilitar su incorporación a los diferentes sistemas de alimentación ovina presentes en la región tropical.

Particularmente, las semillas de Canavalia ensiformis muestran un contenido de energía metabolizable (EM) de 3.35 Mcal kg MS-1(7), la proteína cruda fluctúa entre 22.8 y $35.3 \%$ y la presencia de almidón entre 24.7 y $36.9 \%(5,8)$. Sin embargo, el almidón de semillas crudas de leguminosas presenta una baja digestibilidad, con respecto a los almidones de cereales y tubérculos $(9,10)$. Adicionalmente, las semillas de canavalia poseen diversos factores antinutrientes (canavalina, concanavalina A y B, canavanina, canalina y taninos) que limitan su incorporación en las dietas para monogástricos y posiblemente también en rumiantes $(1,5)$. En términos generales los factores antinutrientes presentes en las semillas crudas de $C$. ensiformis reducen el consumo de alimento y su utilización por los animales monogástricos $(4,11)$.

En estudios efectuados con ovinos en crecimiento $(1,12)$ se indica que la harina de semillas de $\mathrm{C}$. ensiformis puede incorporarse hasta en un $28 \%$ sin que se hayan detectado problemas de salud en los animales. Sin embargo, la ganancia diaria de peso (GDP) que se ha obtenido con diferentes niveles de inclusión ha sido variable. En ovinos machos el
To elaborate diets for sheep, different ingredients are used, highlighting those that provide energy and protein, because these type of ingredients can have a high economic value for themselves, or because they have a significant percentage share in the diet composition.

In the specific case of the protein ingredients of vegetable origin, the tropical region of Mexico has edaphic and climatic conditions that allow the development of tropical leguminous, which produce seeds with a high potential to be incorporated into the diet of sheep. However, this type of seeds require complementary research to the already existing(1-6), in order to facilitate its incorporation into various systems of sheep feeding in the tropical region.

In particular, the seeds of Canavalia ensiformis show content of metabolizable energy (ME) of 3.35 Mcal per kilogram of dry matter (DM) (7), crude protein fluctuates between 22.8 and $35.3 \%$ and the presence of starch between 24.7 and $36.9 \%(5,8)$. However, raw seeds of legume starch have a low digestibility, with respect to the starch from cereals and tubers $(9,10)$. Additionally, the seeds of canavalia have a variety of antinutritional factors (canavaline, concanavalin A and B, canavanine, canaline and tannins) that limit their inclusion in diets for monogastric and possibly also in ruminants $(1,5)$. In general terms the antinutritional factors present in the raw seeds of $C$. ensiformis reduce feed intake and its use for monogastric animals $(4,11)$.

Studies carried out with growing $\operatorname{lambs}(1,12)$ indicated that $28 \%$ of the meal from C. ensiformis seeds can safely be incorporated without health problems. However, the average daily gain (ADG) obtained with different levels of inclusion has been variable. Feed intake of male ovine with $30 \%$ of meal from canavalia seeds reduces the ADG, with respet to $22 \%$ (97 vs $127 \mathrm{~g}$, respectively) (1). In contrast, in another study(12) with Pelibuey lambs the ADG was similar when feed contained 14 and $28 \%$ of canavalia seeds. 
consumo de alimento con $30 \%$ de harina de semillas de $C$. ensiformis reduce la GDP, con respecto a $22 \%$ (97 vs $127 \mathrm{~g}$, respectivamente)(1). En contraste, en otro estudio(12) efectuado con corderos Pelibuey no se detectaron diferencias en la GDP cuando el alimento contenía 14 y $28 \%$ de semillas de canavalia. Adicionalmente, no existen estudios en donde se haya evaluado la alimentación con semillas de canavalia sobre el rendimiento de la canal de ovinos.

La utilización de semillas de canavalia en la alimentación de ovinos se ha realizado fundamentalmente con harina de semillas crudas de canavalia. De ahí que resulta necesario evaluar si la aplicación de un proceso tecnológico al alimento con semillas crudas de canavalia permite aumentar la eficiencia de crecimiento de los ovinos. Por ejemplo, cuando se somete un alimento al proceso de fermentación en estado sólido se incrementa su calidad nutritiva, y en el caso particular de un alimento elaborado con semillas crudas de canavalia es probable que este proceso contribuya a eliminar, reducir o inactivar a los factores antinutrientes presentes en las semillas de canavalia $(13,14,15)$. Con base en estos antecedentes, el objetivo del estudio consistió en determinar la influencia de un alimento fermentado en estado sólido, elaborado con semillas de $\mathrm{C}$. ensiformis como fuente de proteína, sobre el comportamiento productivo y características de la canal de ovinos Pelibuey.

El estudio se realizó en la finca comercial "El Rodeo", ubicada en Jalapa, Tabasco, México ( $17^{\circ}$ 38' N, 920 56' O). El clima de la región es cálido húmedo, con lluvias todo el año (Af), la temperatura ambiente media anual de $25^{\circ} \mathrm{C}$ y la precipitación pluvial anual 3,783 mm(16). Durante el estudio se midió diariamente la temperatura ambiente al abrigo mínima y máxima (ocurrida en 24 h) con un termómetro tipo Six a las $0800 \mathrm{~h}$. Con los datos se calcularon los promedios generales y los promedios en periodos de 14 días. Los promedios generales en la temperatura mínima y máxima fueron $21.01 \pm 1.1$ y $23.7 \pm 2.3^{\circ} \mathrm{C}$. La duración del estudio fue de 86 días y se dividió en una fase
Additionally, there are no studies for evaluation of canavalia on the lamb carcass yield.

The use of canavalia seeds for feeding lambs has been done primarily with canavalia seeds flour. That is why it is necessary to assess whether the implementation of a technological process to the feed with raw seeds of canavalia allows to increase the efficiency of growing lambs. For example, when a feed is subjected to the process of solid-state fermentation increases as nutritious, and in the particularly case of a feed elaborated with raw seeds of canavalia is likely that this process will help to eliminate, reduce or inactivate antinutritional factors present in the canavalia seeds $(13,14,15)$. Based on this background, the objective of the study was to determine the influence of a feed fermented in solid state, made with $\mathrm{C}$. ensiformis seeds as a source of protein, on the productive performance and carcass characteristics of Pelibuey lambs.

The study was conducted at the "El Rodeo" commercial farm, located in Jalapa, Tabasco, Mexico $\left(17^{\circ} 38^{\prime} \mathrm{N}, 92^{\circ} 56^{\prime} \mathrm{W}\right)$. The climate of the region is warm humid with rains throughout the year (Af), the ambient average annual temperature of $25{ }^{\circ} \mathrm{C}$ and annual rainfall of $3,783 \mathrm{~mm}^{(16)}$. During the study the daily ambient temperature minimum and maximum (which occurred in $24 \mathrm{~h}$ ) was measured with a thermometer type Six at $0800 \mathrm{~h}$. With the data general averages and averages of periods of 14 $\mathrm{d}$ were calculated. The general averages of the minimum and maximum temperature were 21.01 \pm 1.1 and $23.7 \pm 2.3^{\circ} \mathrm{C}$. The duration of the study was $86 \mathrm{~d}$ and was divided in a pre-14$d$ phase and two experimental phases: growth (70 d) and carcass evaluation.

\section{Growth study}

The study used 18 Pelibuey lambs with an average age of $4 \mathrm{mo}$ and a live weight of 21 $\pm 1.0 \mathrm{~kg}$. They were randomly distributed to one of three treatments (six lambs per 
pre-experimental de 14 días y dos fases experimentales: crecimiento (70 días) y evaluación de la canal.

\section{Estudio del crecimiento}

Se utilizaron 18 ovinos Pelibuey con una edad promedio de cuatro meses y un peso vivo (PV) de $21 \pm 1.0 \mathrm{~kg}$. Se distribuyeron al azar a uno de tres tratamientos (seis ovinos por tratamiento). Se utilizó un diseño completamente al azar con medidas repetidas en un factor(17). El primer factor fue el tipo de dieta [alimento sin fermentar con canavalia (SFC), alimento fermentado con canavalia (FC), alimento sin fermentar y sin canavalia (SFSC)]. El segundo factor fue el número de periodo de evaluación (cinco períodos de 14 días para evaluar cambios en el peso vivo o 10 de siete días para evaluar cambios en el consumo de nutrimentos). La unidad experimental fue el ovino. Durante el estudio, un cordero del tratamiento sin canavalia se murió por causas no atribuibles a los tratamientos (neumonía). treatment). A completely randomized design was used with measures repeated in a factor(17). The first factor was the type of diet [unfermented feed with canavalia (UFC), fermented feed with canavalia (FC), unfermented feed without canavalia (UFWC)]. The second factor was the number of evaluation period (five periods of $14 \mathrm{~d}$ to evaluate changes in live weight or 10 periods of seven days to evaluate changes in the nutrient intake). The experimental unit was the lamb. During the study, a lamb of the treatment without canavalia died by causes not related to treatments (pneumonia).

Lambs were individually fed throughout the study with isoenergetic and isoproteinic diets (Table 1). At the beginning of the study, each lamb received $500 \mathrm{~g} \mathrm{~d}^{-1}$ of feed according to the treatments. Subsequently, the amount was adjusted daily, based on the intake, trying to maintain at least $10 \%$ of refused feed. The feed was offered from 0800 to $1800 \mathrm{~h}$. Lambs had free access to water.

Cuadro 1. Composición estimada de alimentos elaborados con canavalia en corderos Pelibuey durante la fase de finalización

Table 1. Estimated composition of feeds made with canavalia in Pelibuey lambs during finishing phase

\begin{tabular}{lrrr}
\hline & \multicolumn{3}{c}{ Type of feed } \\
\cline { 2 - 4 } & UFC & FC & UFWC \\
\hline Canavalia seeds meal & 25.0 & 25.0 & 0.0 \\
Soybean meal & 0.0 & 0.0 & 20.0 \\
Maize grain & 32.7 & 32.7 & 40.7 \\
Stylosanthes guianensis hay & 15.0 & 5.0 & 15.0 \\
GM 5 Brachiaria brizantha hay & 7.0 & 10.0 & 4.0 \\
Molasses & 15.0 & 10.0 & 15.0 \\
Vegetable oil & 3.0 & 3.0 & 3.0 \\
Vitafer & 0.0 & 12.0 & 0.0 \\
Amonium sulphate & 0.3 & 0.3 & 0.3 \\
Mineral salt & 2.0 & 2.0 & 2.0 \\
Total & 100.0 & 100.0 & 100.0 \\
Nutrients & & & \\
Crude protein, \% & 17.10 & 17.19 & 17.01 \\
ME, Mcal kg DM-1 (estimated) & 2.94 & 2.96 & 2.92 \\
\hline
\end{tabular}

$\mathrm{UFC}=$ Unfermented feed with canavalia; $F C=$ Fermented feed with canavalia; UFWC $=$ Unfermented feed without canavalia. 
Los corderos se alimentaron de manera individual durante todo el estudio. Las dietas experimentales se formularon para que resultaran isoenergéticas e isoproteínicas (Cuadro 1). Al inicio del estudio, cada cordero recibió $500 \mathrm{~g}$ diarios de alimento de acuerdo a los tratamientos. Posteriormente, la cantidad se ajustó diariamente, de acuerdo al nivel de consumo por cada ovino, procurando mantener al menos un $10 \%$ de alimento rechazado. El alimento se ofreció de 0800 a 1800 h. Los ovinos tuvieron acceso a agua a libertad.

El tratamiento FC incluyó dentro de su composición harina de semillas crudas de C. ensiformis, Vitafert (producto biológicamente activo, rico en lactobacilos y levaduras, obtenido por fermentación líquida); pasta de soya $4.0 \%$, pulidura de arroz $4.0 \%$, melaza de caña $15 \%$, sal mineral $0.5 \%$, urea $0.4 \%$, sulfato de amonio $0.3 \%$, yogurt natural $5.0 \%$ agua 70.8 (15) y se sometió al proceso de fermentación en estado sólido(14) por un mínimo de 10 días. El tratamiento SFC incluyó como parte de la composición harina de semillas crudas de C. ensiformis (este tipo de dieta sólo se utilizó con un máximo de tres días de elaboración).

En las dietas experimentales se determinó: materia seca (MS), proteína cruda (PC), materia orgánica (MO)(18); fibra detergente neutra (FDN) y fibra detergente ácida (FDA)(19), degradación in situ de la MS (DIMS)(20) y energía metabolizable (EM, Mcal kg MS-1)(21).

La DIMS de las tres dietas experimentales se determinó a las $36 \mathrm{~h}$ en dos bovinos híbridos (Bos indicus $x$ Bos taurus), castrados y provistos con cánula en el rumen, con un PV promedio de $500 \mathrm{~kg}$, alojados en corrales individuales, con agua y sal mineral a libertad. Los animales se adaptaron durante 21 días a una ración basada en pastoreo en una pradera mixta con los pastos humidícola (Brachiaria humidicola) y camalote (Paspalum fasciculatum).

Las variables evaluadas en los animales fueron: PV, ganancia diaria de peso (GDP), consumo diario de MS (kg ovino-1), PC (g ovino-1), EM
The FC treatment included within its composition, meal of raw seeds of $C$. ensiformis; Vitafert (biologically active, rich in Lactobacilli and yeast, product obtained by liquid fermentation); soybean meal $4.0 \%$, rice polish $4.0 \%, 15 \%$, mineral salt 0.5 molasses $\%$, urea $0.4 \%, 0.3 \%$ ammonium sulfate, natural yoghurt $5.0 \%$, water 70.8 (15) and subjected to the process of solid fermentation(14) for a minimum of $10 \mathrm{~d}$. UFC treatment was included as part of the meal of raw seeds of canavalia (this type of diet was only used with a maximum of $3 \mathrm{~d}$ of preparation).

The components determination in diets were: dry matter $(D M)$, crude protein $(C P)$, organic matter (OM)(18); neutral detergent fiber (NDF) and acid detergent fiber (ADF)(19) in situ degradation of the DM (IDDM) (20) and metabolizable energy (ME, Mcal kg DM-1)(21). The IDDM of the three experimental diets was determined at $36 \mathrm{~h}$ in two hybrids bovines (Bos indicus $x$ Bos taurus), castrated and provided with a rumen cannula, with an average weight of $500 \mathrm{~kg}$, housed in individual pens with water and mineral salt at freedom. Animals adapted for $21 \mathrm{~d}$ with a ration based on grazing in a meadow mixed with humidicola pastures (Brachiaria humidicola) and camalote (Paspalum fasciculatum).

The variables evaluated in animals were: live weight (LW), average daily gain (ADG), DM daily feed intake ( $\left.\mathrm{kg} \mathrm{lamb}^{-1}\right), \mathrm{CP}$ (g lamb-1), ME (Mcal lamb-1), NDF (g lamb-1), ADF (g lamb-1), as well as feed conversion rate (FCR) and feed efficiency (FE). Sheep were weighed by three consecutive days at $14 \mathrm{~d}$ intervals during six times. On each occasion, the average number of LW corresponded to the average weight of the three consecutive weightings. An electronic scale was used (Tru-Test Pro II version $3.2 \AA$ ), with an accuracy of $0.100 \mathrm{~kg}$.

Feed intake by lamb was determined during three consecutive days every $7 \mathrm{~d}$. Daily intake of $\mathrm{DM}, \mathrm{CP}, \mathrm{ME}, \mathrm{NDF}$ and ADF was determined in $10 \mathrm{wk}$; for this it was considered the feed intake (humid basis) and the mean values of 
(Mcal ovino-1), FDN (g ovino-1), FDA (g ovino-1), así como conversión alimenticia (CA) y eficiencia alimenticia (EA).

Los ovinos se pesaron tres días consecutivos a intervalos de 14 días durante seis ocasiones. En cada ocasión, el promedio de PV correspondió al peso promedio de los tres pesajes consecutivos. Para los pesajes se utilizó una báscula electrónica (Tru-Test Pro II versión $\left.3.2{ }^{\circledR}\right)$, con una precisión de $0.100 \mathrm{~kg}$.

El consumo de alimento por ovino se determinó durante tres días consecutivos a intervalos de siete días. El consumo diario de MS, PC, EM, FDN y FDA se determinó en diez semanas; para ello se consideró el consumo de alimento (base húmeda) y los valores promedio de MS, PC, EM, FDN y FDA determinados en diez muestras (por duplicado) de cada una de las dietas experimentales (Cuadro 2). La CA se determinó a través de la relación consumo de MS:ganancia de peso. La EA correspondió a la relación ganancia de peso:consumo de MS.

En las variables PV, GDP y consumo de MS, PC, EM, FDN y FDA se utilizó análisis de varianza con el procedimiento MIXED(22) con apoyo en
$\mathrm{DM}, \mathrm{CP}, \mathrm{ME}, \mathrm{NDF}$ and ADF determined in ten samples (in duplicate) of each one of the experimental diets (Table 2). The FCR was determined through the DM intake: weight gain ratio. The FE corresponded to weight gain:DM intake relationship.

Analysis of variance with the MIXED procedure was used(22)-I in the LW, ADG and DM intake $\mathrm{CP}, \mathrm{ME}, \mathrm{NDF}$ and $\mathrm{ADF}$ variables with support of the computer program(23). Comparison of means was performed with the " $\mathrm{t}$ " test by square means using the SAS pdiff option. FCR and FE data were analyzed with the Wilcoxon rank sum test for non-paired data(23).

Carcass study

At the end of the growth stage all lambs were slaughtered at the Federal Inspection Slaughterhouse 51 in Villahermosa, Tabasco, Mexico. Carcasses were weighed and introduced (for $24 \mathrm{~h}$ ) in a cooling chamber $\left(0\right.$ to $4{ }^{\circ} \mathrm{C}$ ). Commercial hot carcass yield (carcass weight/ slaughter weight $\times 100$ ) was calculated. The Longissimus dorsi muscle area was measured in the cold carcass between the $12^{\text {th }}$ and $13^{\text {th }}$ rib vertebra by means of a square plastic film

Cuadro 2. Composición química determinada de alimentos elaborados con canavalia para corderos Pelibuey durante la fase de finalización

Table 2. Chemical composition of feeds elaborated with canavalia for finishing Pelibuey lambs

\begin{tabular}{lccc}
\hline & \multicolumn{3}{c}{ Type of feed } \\
\cline { 2 - 4 } & UFC & FC & UFWC \\
\hline DM, \% & $83.0 \pm 1.2 \mathrm{a}$ & $74.4 \pm 0.8 \mathrm{~b}$ & $83.2 \pm 1.0 \mathrm{a}$ \\
CP, \% & $16.2 \pm 0.4 \mathrm{~b}$ & $17.1 \pm 0.3 \mathrm{~b}$ & $18.8 \pm 0.5 \mathrm{a}$ \\
ME, Mcal kg DM-1 (estimated) & $2.8 \pm 0.1$ & $2.7 \pm 0.1$ & $2.8 \pm 0.1$ \\
NDF, \% & $30.6 \pm 1.5$ & $27.0 \pm 1.0$ & $29.4 \pm 1.7$ \\
ADF, \% & $14.5 \pm 1.2$ & $12.3 \pm 0.5$ & $13.9 \pm 0.9$ \\
Ashes, \% & $7.2 \pm 0.4$ & $7.3 \pm 0.5$ & $8.0 \pm 0.6$ \\
Organic matter, \% & $92.8 \pm 0.4$ & $92.7 \pm 0.5$ & $92.0 \pm 0.6$ \\
IDDM, \% & $77.2 \pm 1.2$ & $73.7 \pm 1.2$ & $78.0 \pm 1.5$ \\
n & 10 & 10 & 10 \\
\hline
\end{tabular}

$\mathrm{UFC}=$ Unfermented feed with canavalia; $F C=$ Fermented feed with canavalia; UFWC $=$ Unfermented feed without canavalia. $\mathrm{DM}=$ Dry matter; $\mathrm{CP}=$ Crude protein; $\mathrm{ME}=$ Metabolizable energy; $\mathrm{NDF}=$ Neutral detergent fiber; $A D F=$ Acid detergent fiber; IDDM= in situ degradation of dry matter after incubation for $36 \mathrm{~h}$.

ab Values with distinct superscript in rows are different $(P<0.05)$. 
el programa computacional(23). La comparación de medias se realizó con la prueba de " $\mathrm{t}$ " con las medias de mínimos cuadrados usando la opción pdiff de SAS. Los datos de CA y EA se analizaron con el test suma de rangos de Wilcoxon para datos no pareados(23).

Estudio de la canal

Al finalizar el estudio de crecimiento se sacrificaron todos los ovinos en el rastro Tipo Inspección Federal No. 51 de Villahermosa, Tabasco, México. Las canales se pesaron y se introdujeron (durante $24 \mathrm{~h}$ ) en una cámara de refrigeración ( 0 a $4{ }^{\circ} \mathrm{C}$ ). Se calculó el rendimiento comercial en canal caliente (peso de la canal/peso de sacrificio x 100).

En la canal fría se midió el área del músculo Longissimus dorsi entre la 12a y $13^{\mathrm{a}}$ vertebra torácica, por medio de una película plástica cuadriculada en centímetros cuadrados(24). Así mismo, se midió la distancia del diámetro mayor en sentido medio lateral (A) y del diámetro menor en sentido dorso-ventral (B)(25). La canal fría se dividió en cinco cortes primarios: cuello, brazo-brazuelo, tórax, abdomen y pierna(26).

Las variables evaluadas fueron: peso de la canal caliente y fría $(\mathrm{kg})$, rendimiento de la canal caliente (\%), área, diámetro mayor y menor del músculo L. dorsi, grasa de cobertura $(\mathrm{mm})$ y peso de los cortes primarios $(\mathrm{kg})$. Se utilizó análisis de varianza con el procedimiento GLM(17) con apoyo en un programa computacional(23). La comparación de medias se realizó con la prueba de " $\mathrm{t}$ " con las medias de mínimos cuadrados usando la opción pdiff(23). Los datos de rendimiento de la canal se analizaron con el test Kruskal Wallis; cuando se detectó influencia del tratamiento sobre la variable de respuesta, se aplicó el test de la suma de rangos de Wilcoxon para datos no pareados(23).

En el Cuadro 2 se muestra la composición química determinada de las tres dietas experimentales. La DIMS en las dos dietas con canavalia fue menor a la que se podía esperar normalmente, en ovinos a las $24 \mathrm{~h}(80 \%)^{(27)}$ grid in centimeters(24). Likewise, measured the distance of the greater diameter in middle lateral way (A) and the diameter in back-ventral direction (B) (25). Cold carcass was divided into five primal cuts: neck, arm, thorax, abdomen and leg(26).

The variables evaluated were: carcass weight hot and cold ( $\mathrm{kg})$, hot carcass yield (\%), area, greater and lesser diameters of the $\mathrm{L}$. dorsi muscle, fat $(\mathrm{mm})$ and weight of the primal cuts $(\mathrm{kg})$. Analysis of variance with the GLM procedure(17) with support in a computer program was used for the data(23). The comparison of means was performed with the " $t$ " test by square means with the pdiff(23). Carcass yield data were analyzed using the Kruskal Wallis test. When influence of treatment on the response variable was detected, it was applied the Wilcoxon rank sum test for nonpaired data(23).

The given chemical composition of the three experimental diets are shown in Table 2 . The IDDM in the two canavalia diets was less than expected normally in sheep at $24 \mathrm{~h}(80 \%)(27)$ and $48 \mathrm{~h}(89 \%)(12)$, as well as lower than expected in cattle at $36 \mathrm{~h}(98.9 \%)(28)$. The differences between studies are probably attributed to the time used to determine the IDDM. There is evidence (1) about a tendency to reduce the IDDM as the canavalia seeds level increases in the diet of sheep $(62 \%$ in diets containing $0 \%$ of canavalia; $59 \%$ with $22 \%$ of canavalia and $57 \%$ with $32 \%$ of canavalia). IDDM values in FC and UFC diets are similar to the UFWC diet. This circumstance favors the use of canavalia as an ingredient for ruminants.

Feed and nutriments intake

Type of diet, number of period and their interaction affected $(P<0.01)$ intake of all nutrients studied, but without difference in the intake level $(P>0.05)$ due to feed fermentation. The higher increased nutrients intake $(P<0.05)$ was detected in UFWC treatment (Table 3). 
y 48 h $(89 \%)(12)$, así como menor a la esperada en bovinos(28) a las $36 \mathrm{~h}(98.9 \%)$. Las diferencias entre estudios probablemente sean atribuidas a los tiempos utilizados para determinar la DIMS. Por otra parte, existen evidencias(1) que refieren una tendencia a reducir la DI MS conforme se incrementa el nivel de harina de semillas de canavalia en la dieta de los ovinos (62\% en dietas con $0 \%$ de canavalia; $59 \%$ con $22 \%$ de canavalia y $57 \%$ con $32 \%$ de canavalia).

Los valores DIMS en las dietas FC y SFC son similares al de la dieta SFSC; esta circunstancia favorece que las semillas de canavalia sean consideradas como un ingrediente que puede ser parte de un alimento para rumiantes.

\section{Consumo de alimento y nutrimentos}

El tipo de dieta, número de período y su interacción, afectaron $(P<0.01)$ el consumo de todos los nutrimentos estudiados, pero no se detectó diferencia en el nivel de consumo $(P>0.05)$ por efecto de la fermentación en el alimento. El mayor consumo de nutrimentos $(P<0.05)$ se detectó en los ovinos que consumieron la dieta SFSC (Cuadro 3).

Los ovinos que consumieron las dietas FC $y$ SFC mostraron un menor consumo de MS (y por
Sheep fed FC and UFC diets showed a lower DM intake (and therefore of its components) in at least $27 \%$ vs the UFWC diet. This result is not consistent with that reported in sheep $(1,12,29)$ where it was noted that the inclusion of canavalia seeds in levels from 10 to $32 \%$ did not affect feed intake. On the other hand, there are not studies who evaluate the influence of the level of canavalia seeds meal in feedstuff for sheep on its palatability. Only, it has been suggested( 30 ) that canavalia shows low palatability when used as complement forage for sugar cane juice in comparison with other fiber sources (bran wheat, forage of sweet potatoes and Brachiaria decumbens). It is likely that lower DM intake detected in diets with canavalia seeds meal is attributed to a low palatability.

Intake of $\mathrm{DM}, \mathrm{ME}, \mathrm{CP}, \mathrm{NDF}$ and $\mathrm{ADF}$ were influenced by the number of period $(P<0.01)$. In particular, ME intake remained similar in the first two periods. Subsequently increased and remained almost constant in the rest of the periods, with the exception of the period 8 where increased to $2.8 \mathrm{Mcal} \mathrm{d}^{-1}$ lamb-1 $^{-1}$ (Figure $1)$.

Intake of DM, CP, NDF and ADF considering the number of period, showed a similar trend as the DM. The increase in ME intake showed

Cuadro 3. Influencia de la fermentación en dietas elaboradas con semillas de Canavalia ensiformis sobre el consumo de nutrimentos en corderos Pelibuey en finalización

Table 3. Influence of fermentation in diets with Canavalia ensiformis seeds on nutrient intake of finishing Pelibuey lambs

\begin{tabular}{|c|c|c|c|}
\hline & \multicolumn{3}{|c|}{ Type of diet } \\
\hline & UFC & FC & UFWC \\
\hline Dry matter, $g d^{-1}$ sheep-1 $^{-1}$ & $796 \pm 60 a$ & $775 \pm 60.0 \mathrm{a}$ & $1,096 \pm 66 b$ \\
\hline$C P, g^{-1}$ sheep $^{-1}$ & $129 \pm 11 a$ & $132 \pm 11.0 \mathrm{a}$ & $206 \pm 12 b$ \\
\hline ME, Mcal kg DM-1 & $2.2 \pm 0.16^{a}$ & $2.1 \pm 0.16 a$ & $3.1 \pm 0.18^{b}$ \\
\hline NDF, g d-1 sheep-1 & $243 \pm 17.0 \mathrm{a}$ & $209 \pm 17.0 \mathrm{a}$ & $322 \pm 18.6 \mathrm{~b}$ \\
\hline$A D F, g^{-1}$ sheep $^{-1}$ & $115 \pm 7.9 a$ & $95 \pm 7.9 a$ & $152 \pm 8.7 b$ \\
\hline
\end{tabular}

UFC = Unfermented feed with canavalia; $F C=$ Fermented feed with canavalia; UFWC $=$ Unfermented feed without canavalia; $\mathrm{CP}=$ Crude protein; $\mathrm{NDF}=$ Neutral detergent fiber; $\mathrm{ADF}=$ Acid detergent fiber.

ab Values with distinct superscript in rows are different $(P<0.05)$. 
Figura 1. Efecto del número de período de estudio sobre el consumo de energía metabolizable en corderos Pelibuey en finalización

Figure 1. Effect of number of period on metabolizables energy (ME) intake in finishing Pelibuey lambs

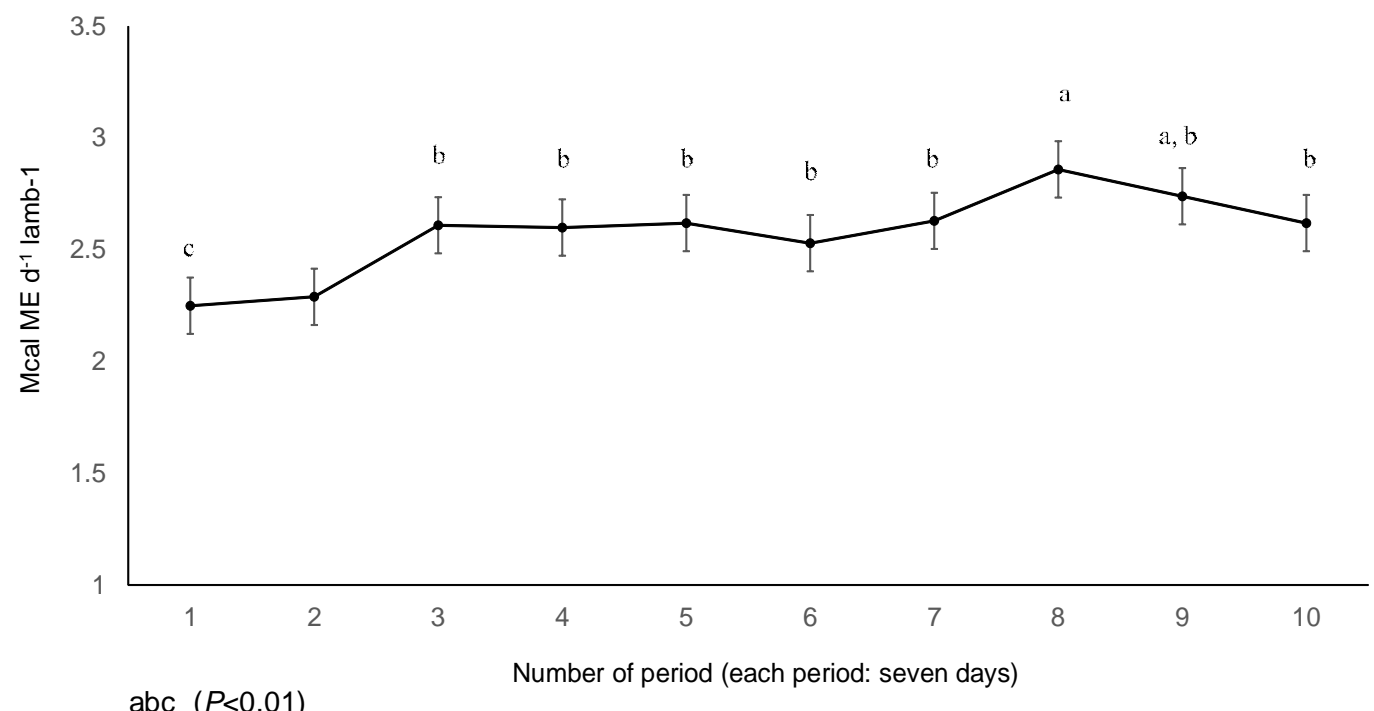

consiguiente el de sus componentes) en al menos $27 \%$ con relación a lo registrado en la dieta SFSC. Este resultado no concuerda con lo reportado en ovinos $(1,12,29)$, donde se observó que la inclusión de semillas de canavalia en niveles de 10 a 32 \% no afectó el consumo de alimento. Por otra parte, no se dispone de estudios en donde se haya evaluado la influencia del nivel de inclusión de harina de semillas de canavalia en el alimento para ovinos sobre su palatabilidad. Únicamente, se ha indicado(30) que la canavalia muestra baja palatabilidad cuando se utiliza como forraje complementario al jugo de caña de azúcar en comparación con otras fuentes de fibra (salvado de trigo, forraje de papas dulces y Brachiaria decumbens). Es probable que el menor consumo de MS detectado en las dietas con harina de semillas de canavalia se atribuya a una baja palatabilidad.

El consumo de MS, EM, PC, FDN y FDA fueron influidos por el número de período $(P<0.01)$. Particularmente, el consumo de EM se mantuvo similar en los dos primeros períodos. Posteriormente se incrementó y se mantuvo by lambs as the study advanced, was attributed to the type of diets used, who allowed to obtain a positive ADG and therefore the animals reached a higher $L W$. A higher $L W$ increases $\mathrm{DM}$ and ME requirements(31).

The interaction type of diet $x$ number of period influenced $(P<0.01)$ intake level of all nutrients studied. Lambs fed UFWC diet showed greater intake of DM, ME, CP, NDF and ADF through the entire period of study VS FC and UFC treatments.

Figure 2 shows ME intake considering the type of diet and period number, as well as the values of maximum temperature in the shelter (average temperature in each period). Lambs in the UFWC treatment had higher ME intake during the entire period of study with respect to the FC and UFC treatments.

In the UFWC treatment ME intake increased through the study, detecting the higher intake in the period 8 . However, between the period 5 and 10 a steady ME intake with small variations was registered. The voluntary intake 
casi constante en el resto de los períodos, con excepción del período 8 en donde se registró el mayor consumo de EM, 2.8 Mcal día-1 ovino-1 (Figura 1).

Los consumos de MS, PC, FDN y FDA considerando el número de período, mostraron un comportamiento similar al registrado en la EM. El incremento en el consumo de EM conforme avanzó el estudio, se atribuye a que el tipo de dietas utilizadas permitieron obtener una GDP positiva y por consiguiente los animales alcanzaron un mayor PV conforme avanzó el estudio; y un aumento en el PV incrementa los requerimientos de MS y $\operatorname{EM(31).~}$

La interacción tipo de dieta $\mathrm{x}$ número de período influyó $(P<0.01)$ sobre el nivel de consumo de todos los nutrimentos estudiados. Los ovinos que consumieron la dieta SFSC mostraron mayor consumo de MS, EM, PC, FDN y FDA a través de todo el período de estudio con relación a lo detectado en los tratamientos FC y SFC. in the ruminant is affected by multiple factors, including physical (distension of the reticulumrumen), hormonal (gastrointestinal hormones) and chemicals (volatile fatty acids)(32).

It is likely that the higher maximum temperature recorded at the site where lambs stayed, limited ME intake (Figure 2). In this respect, it has been documented that an increase in temperature is associated with a reduction in feed intake(33). Additionally, the digestibility value of a diet limits energy intake, when DM digestibility (in diet with high fiber content) is between 67 and $80 \%$, the DM intake decreases as digestibility is increased after adjusting for body weight and energy produced(32). In the present study the IDDM of diet UFWC was greater than $67 \%$.

In several studies $(1,12)$ where canavalia seeds were evaluated in lambs, reported no changes in feed intake in intermediate periods of the study. However, in a work with sheep(12)

Figura 2. Efecto de la fermentación en un alimento con canavalia y de número de período sobre el consumo de energía metabolizable en corderos Pelibuey en finalización

Figure 2. Effect of fermentation and number of period on metabolizable energy intake in finishing Pelibuey lambs

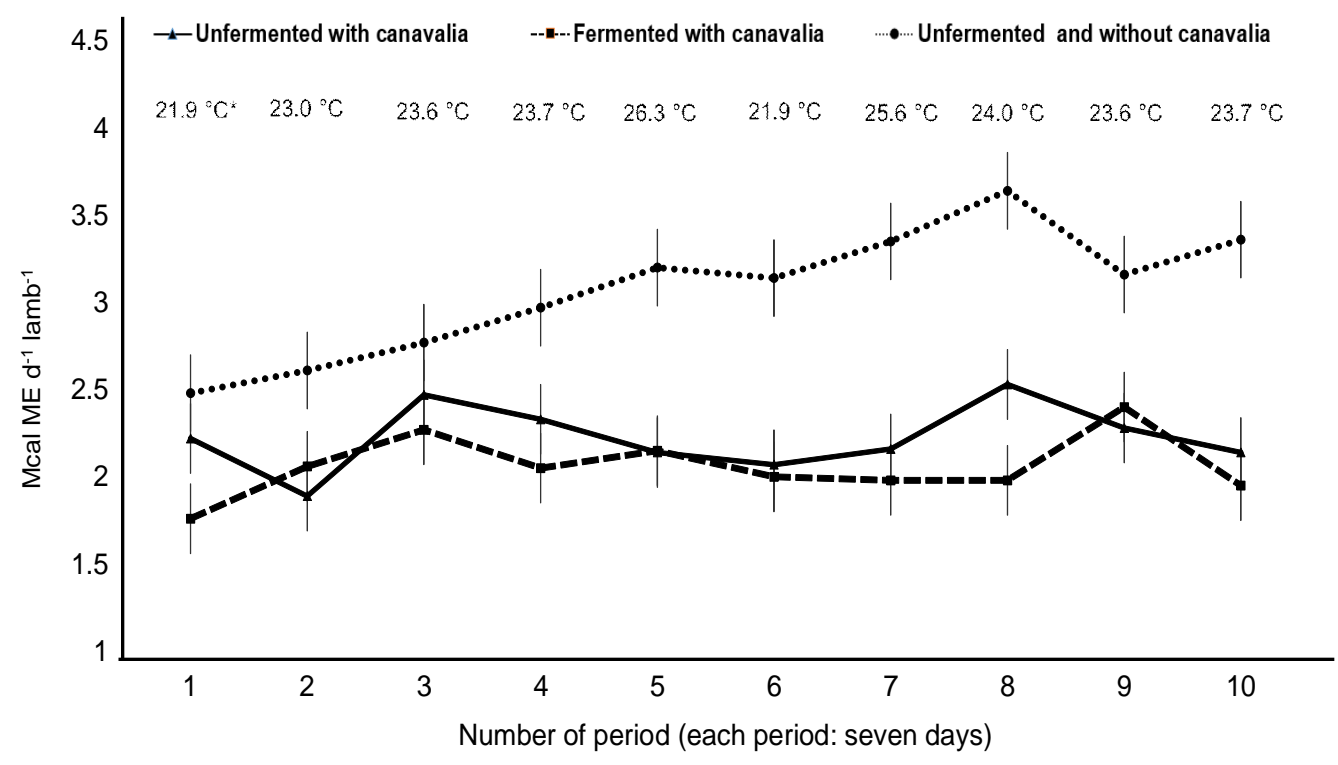

Least squares means ( \pm standard error) $(P<0.01)$. ${ }^{*}$ Maximum shelter temperature. 
En la Figura 2 se muestra el consumo de EM considerando el tipo de dieta y el número de período, así como los valores de temperatura al abrigo máxima (promedio de temperatura en cada período). Los ovinos en el tratamiento SFSC tuvieron mayor consumo de EM durante todo el período de estudio con respecto a los tratamientos FC y SFC.

En el tratamiento SFSC el consumo de EM se incrementó a través del estudio, detectándose el mayor consumo en el período 8. Sin embargo, entre el período 5 y 10 se registra un consumo constante de EM con pequeñas variaciones. El consumo voluntario en los rumiantes es afectado por múltiples factores, entre los cuales destacan factores físicos (distensión del retículo-rumen), hormonales (hormonas gastrointestinales) y químicos (ácidos grasos volátiles)(32).

Es probable que el ascenso en la temperatura máxima que se registró en el sitio donde se alojaron los ovinos haya limitado el consumo de EM (Figura 2). Al respecto, se ha documentado que un incremento en la temperatura ambiente se asocia con una reducción en el consumo de alimento(33). Adicionalmente, el valor de digestibilidad de una dieta limita el consumo de energía, cuando la digestibilidad de la MS (en dietas con alto contenido en fibra) se encuentra entre $67 \mathrm{y}$ $80 \%$, el consumo de MS disminuye conforme se incrementa la digestibilidad después de ajustar para peso vivo y energía producida(32). En el presente estudio la DIMS de la dieta SFSC fue superior al $67 \%$.

En diversas investigaciones $(1,12)$ donde se evaluaron dietas con semillas de canavalia en ovinos, no se reportan cambios en el consumo de alimento en períodos intermedios del estudio. Sin embargo, en un trabajo con ovinos(12) al considerar dos etapas de crecimiento (15 a 24 $\mathrm{kg}$ y 24 a $28 \mathrm{~kg}$ ), no se detectó influencia del nivel de inclusión de canavalia en el alimento. Resultados que no concuerdan con los hallazgos señalados en el presente estudio, en donde los ovinos del tratamiento SFSC muestran considering two stages of growth ( 15 to $24 \mathrm{~kg}$ and 24 to $28 \mathrm{~kg}$ ), was detected an influence of the level of canavalia in the feed. Results that do not match with findings identified in this study, where the lambs of the UFWC treatment showed marked differences in ME intake, from the third period, to the end of the study vs FC and UFC diets. This may be due to the presence of anti-nutritional factors in the canavalia seeds, which could be related to reduction of DM intake. In this regard, it has been proposed(34) that the ruminal medium is a place of detoxification of substances present in the feed for ruminants. However, it is possible that for the case of the antinutritional factors present in the canavalia seeds, the ruminal environment was not fully effective to minimize the negative effects of these factors.

With the exception of the period 8, ME intake in FC and UFC diets within the same period was similar $(P>0.05)$. The above situation indicates that fermentation applied to the feed with canavalia did not affect intake of this type of diet.

Growth

Type of diet affected LW $(P<0.05)$ and ADG $(P<0.01)$ of lambs. The UFWC diet allowed a higher LW and ADG in relation to UFC and FC diets. The least squares means $( \pm \mathrm{SE}$ ) were $29.9 \pm 1.6 \mathrm{~kg}$ and $195 \pm 14.6 \mathrm{~g}, 23.0 \pm 1.6$ $\mathrm{kg}$ and $62 \pm 13.4 \mathrm{~g}, 24.4 \pm 1.4 \mathrm{~kg}$ and $107 \pm$ $13.4 \mathrm{~g}$, respectively. ADG obtained in treatments with canavalia was less than that reported in other studies with sheep $(1,12)$. In Pelibuey males(12) ADG varied between 190 and $220 \mathrm{~g}$ in animals fed with canavalia, while in diets where canavalia seeds meal replaced partially the soybean meal, the ADG was between 98 and $127 \mathrm{~g}^{(1)}$.

The lower ADG detected in FC and UFC diets can be attributed to lower DM intake compared to the UFWC diet, which meant an intake reduction of 32 and $37 \% \mathrm{ME}$ and $\mathrm{CP}$ respectively. In addition, it is important to 
diferencias marcadas en el consumo de EM, a partir del tercer período y hasta concluir el estudio con respecto a lo detectado en las dietas FC y SFC. Lo anterior, puede ser debido a la presencia de factores antinutrientes en las semillas de canavalia, los cuales pudieran estar relacionados con la reducción en el consumo de MS. Al respecto, se ha propuesto(34) que el medio ruminal es un lugar de desintoxicación de sustancias presentes en el alimento que ingiere el rumiante. Sin embargo, es posible que para el caso de los factores antinutrientes presentes en las semillas de canavalia, el medio ruminal no haya sido plenamente eficaz para minimizar los efectos negativos de estos factores.

Con excepción del período 8, el consumo de EM en las dietas FC y SFC dentro del mismo período resultó similar $(P>0.05)$. Esto indica que el proceso de fermentación aplicado al alimento con canavalia no afectó el consumo de este tipo de dietas.

\section{Crecimiento}

El tipo de dieta afectó el PV $(P<0.05)$ y la GDP $(P<0.01)$. El consumo de la dieta SFSC permitió que los ovinos mostraran un mayor PV y GDP con relación a las dietas SFC y FC. Las medias de cuadrados mínimos ( \pm EE) fueron $29.9 \pm$ $1.6 \mathrm{~kg}$ y $195 \pm 14.6 \mathrm{~g}, 23.0 \pm 1.6 \mathrm{~kg}$ y $62 \pm$ $13.4 \mathrm{~g}, 24.4 \pm 1.4 \mathrm{~kg}$ y $107 \pm 13.4 \mathrm{~g}$, respectivamente.

La GDP obtenida en los tratamientos con canavalia fue menor a la reportada en otros estudios con ovinos(1,12). En machos Pelibuey(12) la GDP varió entre 190 y $220 \mathrm{~g}$ al consumir canavalia, mientras que en dietas donde la harina de semillas de canavalia reemplazó parcialmente a la pasta de soya se obtuvo una GDP entre 98 y $127 \mathrm{~g}(1)$.

La menor GDP detectada en las dietas FC y SFC puede atribuirse al menor consumo de MS con relación a la dieta SFSC, el cual significó una reducción en el consumo de EM y PC del orden del 32 y $37 \%$. Adicionalmente, es consider that an increase in the level of canavalia seeds meal reduces digestibility of cell wall components; with canavalia levels of 0,22 , and $32 \%$ digestibility values were 59,58 and $48 \%$, respectively(1). Some others agree(35) that sheep fed with Pennisetum purpureum and a dietary supplement (cotton seeds meal or C. ensiformis seeds meal) fibrous DM digestibility was $20 \%$ greater for the treatment with cotton seeds with respect to canavalia treatment. In the present study, the experimental diets had between 27.0 and $30.6 \%$ of NDF, and it is likely that in FC and UFC diets the digestibility of the cell walls had been reduced with respect to UFWC, situation that could help to explain the lower ADG. On the other hand, application of the fermentation process to feed with canavalia favored a greater ADG compared to UFC diet. This indicates that fermentation increased feed efficiency, since DM intake was similar in diets with canavalia.

The number of period influenced $(\mathrm{P}<0.01) \mathrm{LW}$ and $A D G$. The $L W$ was increased from the period 1 to $5(21.3 \pm 0.9$ to $29.1 \pm 0.9 \mathrm{~kg})$. However, there was no difference ( $P>0.05)$ during the periods $5(29.1 \pm 0.9)$ and $6(29.4 \pm 0.9)$. The largest ADG was recorded between periods 2 to $3(164 \pm 18 \mathrm{~g})$ and 4 to $5(165 \pm 18 \mathrm{~g})$ and the lowest in the last period of 5 to 6 (165 \pm $18 \mathrm{~g}$ ). The changes detected through time in LW and ADG agrees with a study conducted in Pelibuey sheep male(36), who states that initially the production will have a fast growth as feed supply increases, then, it will be a point where the sheep weight will tend to decrease at unsatisfactory levels.

Additionally, when sheep achieved a feed intake level allowing to meet maintenance and growth requirements (measured through a positive ADG), the response is a sustained over time weight gain $(31,37,38)$. In this regard, it has been suggested(31) that to obtain an ADG of $150 \mathrm{~g}$, lambs with 20, 25 and $30 \mathrm{~kg}$, should consume 2.7, 3.0 and 3.4 Mcal ME $\mathrm{d}^{-1}$, respectively. In the present study although the lambs showed lower ME daily intake, they achieved an ADG 
importante considerar que un incremento en el nivel de inclusión de harina de semillas de canavalia reduce la digestibilidad de los componentes de la pared celular; con 0,22 y $32 \%$ de canavalia los valores de digestibilidad fueron 59,58 y $48 \%$, respectivamente(1). En concordancia con lo señalado previamente, se ha reportado(35) que ovinos alimentados con Pennisetum purpureum y un complemento alimenticio (harina se semillas de algodón o harina de semillas de C. ensiformis) la digestibilidad de la MS fibrosa fue $20 \%$ mayor para el tratamiento con semillas de algodón con respecto al tratamiento con canavalia. En el presente estudio las dietas experimentales tuvieron entre 27.0 y $30.6 \%$ de FDN, y resulta probable que en las dietas FC y SFC la digestibilidad de las paredes celulares haya sido menor con respecto a la dieta SFSC, situación que pudiera contribuir a explicar la menor GDP. Por otra parte, la aplicación del proceso de fermentación al alimento con canavalia favoreció que los ovinos mostraran una mayor GDP con relación a los que consumieron la dieta SFC; esta situación indica que la fermentación exceeding $150 \mathrm{~g}$, likely attributed to the energy density of the diets used (Table 2), which was exceeding the recommendation for hair sheep(31).

The interaction diet type $x$ number of period affected $(P<0.01)$ LW and ADG. Lambs in UFWC diet showed greater ADG at the beginning of the study (periods 1 to 2), and in the middle of the study (periods 3 to 4 ) with respect to FC and UFC diets (Figure 3). Sheep fed FC diet showed a greater ADG with respect to UFC diet only in period 2 to 3; ADG was similar in the other periods.

With the exception of the last period, in the UFC diet, the ADG recorded throughout the study was positive. However, a tendency to reduce the ADG as the study advanced was detected in the three diets. This has been previously reported(37) in Pelibuey sheep grazing and receiving a feed complement. In the present study, the lamb continued growing (increases in LW and positive ADG) through the study, regardless of the diet. However, the maximum

Figura 3. Efecto de la fermentación y número de período sobre la ganancia diaria de peso (ADG) en corderos Pelibuey en finalización

Figure 3. Effect of fermentation and period on average daily gain (ADG) in finishing Pelibuey lambs

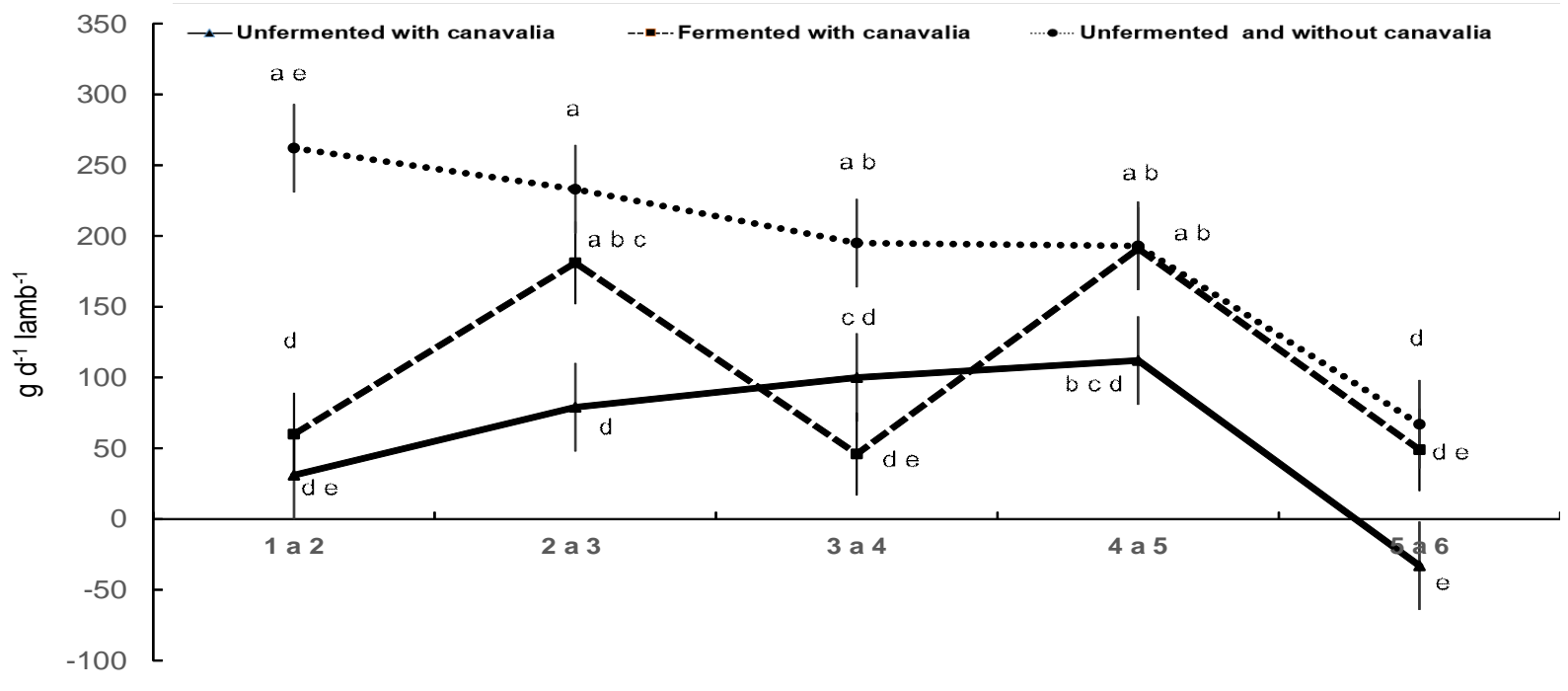

abc $(P<0.01)$

Number of period (each period: 14 days) 
incrementó la eficiencia alimenticia, ya que los consumos de MS fueron similares en las dietas con canavalia.

El número de período influyó $(P<0.01)$ sobre el PV y GDP de los ovinos. El PV se incrementó entre el periodo 1 y 5 de $21.3 \pm 0.9$ a $29.1 \pm$ $0.9 \mathrm{~kg}$. Sin embargo, no se detectaron diferencias $(P>0.05)$ en los periodos 5 (29.1 \pm $0.9)$ y $6(29.4 \pm 0.9)$. La mayor GDP se registró entre los períodos 2 a $3(164 \pm 18 \mathrm{~g})$ y 4 a 5 $(165 \pm 18 \mathrm{~g})$ y la menor en el último período de 5 a $6(165 \pm 18 \mathrm{~g})$. Los cambios detectados a través del tiempo en el PV y GDP corresponden a lo indicado en un estudio efectuado en ovinos machos Pelibuey(36), que muestra que en un inicio la producción tendrá un crecimiento rápido a medida que aumenta el suministro del alimento, posteriormente, se llegará a un punto en el que el peso de los ovinos tenderá a decrecer a niveles no satisfactorios. Adicionalmente, cuando los ovinos logran un nivel de consumo de alimento que permita cubrir sus requerimientos de mantenimiento y crecimiento (medido a través de una GDP positiva), la respuesta es un aumento de peso sostenido a través del tiempo(31,37,38). Al respecto, se ha indicado(31) que para obtener una GDP de $150 \mathrm{~g}$ los ovinos con 20,25 y $30 \mathrm{~kg}$, deben consumir 2.7, 3.0 y weight of the lamb (when the weight of the animal is a function of time), did not represent the maximum biological efficiency, which is consistent with previously data described in Pelibuey lambs(36).

The total ADG, FCR and FE were affected $(P<0.05)$ by type of diet (Table 4). Although ADG was grater in lambs fed by the UFWC vs FC and UFC diets, AC and FE in the UFWC and FC treatments were similar $(P>0.05)$. Lambs with the UFC diet showed the lower ADG and $F E$, as well as greater $A C$ with respect to UFWC and FC diets.

AC obtained with UFWC diet was similar to those reported previously in Pelibuey lambs(12) and lower to indicated in hair sheep(1). However, the FCR in the UFC diet was higher than indicated by Dixon et al(1) who showed a FCR of 8.9 and 10.8 for inclusion levels of canavalia of 22 and $32 \%$, respectively. For his part, Mamani(12) reported a 7.2 AC when the canavalia was included in a $28.2 \%$. Apparently, the low DM intake and the smaller ADG detected in sheep fed UFC diet explains the high AC obtained. In support to this, there are indications that suggest that an increase in the level of raw canavalia seeds in sheep's feed tends to increase the weight of ruminal contents, and possibly reduce its change rate( 1$)$.

Cuadro 4. Medias de cuadrados mínimos ( \pm errores estándar) de variables en corderos Pelibuey con dietas a base de semillas de Canavalia ensiformis

Table 4. Least square means ( \pm standard errors) of variables in Pelibuey lambs with diets based on Canavalia ensiformis seeds

\begin{tabular}{lccc}
\hline & \multicolumn{4}{c}{ Type of diet } \\
\cline { 2 - 4 } Variable & UFC & FC & UFWC \\
\hline Initial weight, $\mathrm{kg}$ & $21.0 \pm 1.1$ & $20.8 \pm 1.1$ & $22.2 \pm 1.2$ \\
Final weight, $\mathrm{kg}$ & $25.2 \pm 1.7 \mathrm{a}$ & $28.0 \pm 1.7 \mathrm{a}$ & $35.5 \pm 1.8 \mathrm{~b}$ \\
ADG, $\mathrm{g}$ & $62.0 \pm 13.4 \mathrm{a}$ & $107.0 \pm 13.4 \mathrm{~b}$ & $195.0 \pm 14.6 \mathrm{c}$ \\
$\mathrm{FCR}$ & $14.9 \pm 3.16 \mathrm{a}$ & $7.5 \pm 0.59 \mathrm{~b}$ & $5.9 \pm 0.36 \mathrm{~b}$ \\
$\mathrm{FE}$ & $0.079 \pm 0.012 \mathrm{a}$ & $0.137 \pm 0.009 \mathrm{~b}$ & $0.173 \pm 0.011 \mathrm{~b}$ \\
$\mathrm{n}$ & 6 & 6 & 5 \\
\hline
\end{tabular}

UFC $=$ Unfermented feed with canavalia; FC= Fermented feed with canavalia; UFWC $=$ Unfermented feed without canavalia; $A D G=$ Average daily gain; $F C R=$ Feed convertion; FE= Feed efficiency.

abc Values with distinct superscript in rows are different $(P<0.05)$. 
3.4 Mcal EM día-1, respectivamente. En el presente estudio los ovinos mostraron un menor consumo diario de EM, sin embargo, lograron una GDP superior a $150 \mathrm{~g}$, posiblemente debido a la densidad energética en las dietas utilizadas (Cuadro 2), la cual resultó superior a la recomendada para ovinos de pelo(31).

La interacción tipo de dieta $\mathrm{x}$ número de período afectaron $(P<0.01)$ el PV y GDP. Los ovinos alimentados con la dieta SFSC mostraron una mayor GDP al inicio del estudio (período 1 a 2) y en la parte intermedia del estudio (período 3 a 4) con respecto a lo detectado en las dietas FC y SFC (Figura 3). Los ovinos que consumieron la dieta FC mostraron una mayor GDP con respecto a la dieta SFC únicamente en el período 2 a 3; en los otros períodos la GDP resultó similar ( $P>0.05)$.

Con excepción del último periodo, en la dieta SFC la GDP registrada durante todo el estudio fue positiva. Sin embargo, en las tres dietas se detectó una tendencia a reducir la GDP conforme avanzó el estudio. Este tipo de comportamiento ha sido reportado previamente(37) en ovinos Pelibuey en pastoreo que reciben una complementación alimenticia. En el presente estudio, los ovinos continuaron creciendo (incrementos en el PV y GDP positiva) a través del estudio, independientemente de la dieta utilizada. Sin embargo, el máximo peso del ovino (cuando el peso del animal está en función del tiempo), no representó la máxima eficiencia biológica, lo cual concuerda con lo indicado previamente en ovinos Pelibuey(36).

La GDP total, CA y EA resultaron afectadas $(P<0.05)$ por el tipo de dieta (Cuadro 4). Aunque los ovinos alimentados con la dieta SFSC mostraron la mayor GDP con respecto a lo detectado en las dietas FC y SFC; la CA y EA en los tratamientos SFSC y FC resultaron similares $(P>0.05)$. Los ovinos con la dieta SFC mostraron la menor GDP y EA, así como la mayor CA con respecto a las dietas SFSC y FC.

La CA obtenida con la dieta SFSC resultó similar a la reportada previamente en ovinos
It is likely that inclusion of canavalia seeds, affects not only the digestibility of the diet(30) and the fibrous fraction of DM digestibility(35), but that the various antinutritional factors (e.g., concanavalin A and canavanine) present in the seeds limit intake of this type of diet. It has been suggested that the lectin (concanavalin A is a lectin) present in $C$. ensiformis and in Phaseolus vulgaris reduces absorption of nutrients by joining the surface of the epithelial cells of the small intestine(4). No studies were found that addressed the possible damage that causes the concanavalin $A$ to the rumen epithelium. While in a study performed in vitro with canavanine(39) was observed that this amino acid inhibits the growth of media of the lactic acid bacteria Lactobacillus arabinosus 175 (8014). The extent of the possible damage of canavanine to bacteria in the rumen will need to be addressed in future studies.

The results obtained in the intake of $C P, M E$, NDF and ADF, as well as the ADG, FCR and FE suggests that application of fermentation in solid state to canavalia diets allowed lambs to show higher growth efficiency in relation to UFC diet. It is suggested that this increased efficiency could be related to a reduction or inhibition of the negative effects of antinutritional factors present in the $\mathrm{C}$. ensiformis seeds. Previous studies(15) show that application of the fermentation process in solid state at the meal of raw C. ensiformis seeds reduces the canavanine concentration $12 \%$ with respect to unfermented seeds, 3.7 vs $4.2 \mathrm{~g} 100 \mathrm{~g} \mathrm{DM}^{-1}$, respectively.

Application of fermentation to feedstuffs with canavalia allowed to increase the productive efficiency of lambs compared to a diet without fermentation, situation that increases the possibilities to include canavalia seeds in finishing diets for sheep in tropical regions.

\section{Carcass features}

With the exception of the hot carcass yield and lower $\mathrm{L}$. dorsi muscle diameter, the rest of the variables studied were affected $(P<0.01)$ for 
Pelibuey(12) y menor a la indicada en ovinos de pelo(1). Sin embargo, la CA en la dieta SFC fue mayor a la señalada por Dixon et al(1) quienes muestran una CA de 8.9 y 10.8 para los niveles de inclusión de canavalia de 22 y $32 \%$, respectivamente. Por su parte, Mamani(12) reportaron una CA de 7.2 cuando la canavalia se incluyó en un $28.2 \%$. Al parecer, el bajo consumo de MS y la menor GDP detectada en los ovinos que consumieron la dieta SFC explica la alta CA obtenida. En apoyo a lo anterior, existen indicios que sugieren que un incremento en el nivel de semillas crudas de canavalia en el alimento de ovinos tiende a incrementar el peso del contenido ruminal, y posiblemente a reducir la tasa de cambio del contenido ruminal(1).

Es probable que la inclusión de semillas de canavalia, no solo afecte la palatabilidad de la the type of diet (Table 5). Lambs receiving the UFWC diet showed greater fat carcass weight and fat coverage, as well as greater weight of the five primal cuts vs FC and UFC diets. However, the area and the greater diameter of the $\mathrm{L}$. dorsi muscle were similar in lambs fed UFWC and FC diets.

The carcass weight is important because it represents the economic value of the products obtained when lamb are slaughtered; the carcass weight of the FC and UFC diets represented the $73.8 \%$ and $67.3 \%$, respectively, of the carcass weight of UFWC diet. This response can be explained, partially, by the increased ME intake that showed the lambs with the UFWC diet. Partida and Martinez $(42)$ mention that an increase in the energy level (from 2.6 to 2.9 Mcal ME $\mathrm{kg} \mathrm{DM}^{-1}$ ) allows to get a heavier carcass in Pelibuey lamb.

Cuadro 5. Medias de cuadrados mínimos ( \pm errores estándar) de variables post mortem en ovinos Pelibuey con dietas en base a semillas de Canavalia ensiformis

Table 5. Least square means ( \pm standard errors) of post mortem variables in Pelibuey sheep fed with diets based on Canavalia ensiformis seeds

\begin{tabular}{lccr}
\hline & \multicolumn{3}{c}{ Type of diet } \\
\cline { 2 - 4 } Variable & UFC & FC & UFWC \\
\hline Slaughter weight, $\mathrm{kg}$ & $25.2 \pm 1.7 \mathrm{a}$ & $28.0 \pm 1.7 \mathrm{a}$ & $35.5 \pm 1.8 \mathrm{~b}$ \\
Hot carcass weight, kg & $11.3 \pm 0.8 \mathrm{a}$ & $12.4 \pm 0.8 \mathrm{a}$ & $16.8 \pm 0.9 \mathrm{~b}$ \\
Cold carcass weight, kg & $11.1 \pm 0.8 \mathrm{a}$ & $12.1 \pm 0.8 \mathrm{a}$ & $16.5 \pm 0.9 \mathrm{~b}$ \\
Hot carcass yield, \% & $44.7 \pm 1.1$ & $44.2 \pm 1.1$ & $47.4 \pm 1.2$ \\
Cold carcass measurements: & & & \\
Longissimus dorsi área, cm² & $9.3 \pm 0.6 \mathrm{a}$ & $10.7 \pm 0.6 \mathrm{~b}$ & $12.5 \pm 0.7 \mathrm{~b}$ \\
L. dorsi large diameter, cm² & $4.8 \pm 0.2 \mathrm{a}$ & $5.2 \pm 0.2 \mathrm{~b}$ & $5.8 \pm 0.2 \mathrm{~b}$ \\
L. dorsi small diameter, cm $\mathrm{cm}^{2}$ & $2.2 \pm 0.1$ & $2.3 \pm 0.1$ & $2.7 \pm 0.2$ \\
Fat, mm & $0.9 \pm 0.4 \mathrm{a}$ & $0.7 \pm 0.4 \mathrm{a}$ & $2.8 \pm 0.4 \mathrm{~b}$ \\
Neck, kg & $1.1 \pm 0.1 \mathrm{a}$ & $1.0 \pm 0.1 \mathrm{a}$ & $1.6 \pm 0.1 \mathrm{~b}$ \\
Chest, kg & $3.0 \pm 0.3 \mathrm{a}$ & $3.5 \pm 0.3 \mathrm{a}$ & $4.8 \pm 0.3 \mathrm{~b}$ \\
Shoulder, kg & $1.9 \pm 0.1 \mathrm{a}$ & $2.2 \pm 0.1 \mathrm{a}$ & $2.7 \pm 0.1 \mathrm{~b}$ \\
Foreshank, kg & $2.4 \pm 0.3 \mathrm{a}$ & $2.8 \pm 0.3 \mathrm{a}$ & $3.8 \pm 0.3 \mathrm{~b}$ \\
Leg, kg* & $2.6 \pm 0.2 \mathrm{a}$ & $2.6 \pm 0.2 \mathrm{a}$ & $3.5 \pm 0.2 \mathrm{~b}$ \\
$\mathrm{~N}$ & 6 & 6 & 5 \\
\hline
\end{tabular}

UFC= Unfermented feed with canavalia; FC= Fermented feed with canavalia; UFWC $=$ Unfermented feed without canavalia.

* Weight of both legs.

ab Values with distinct superscript in rows are different $(P<0.05)$. 
dieta(30) y la digestibilidad de la fracción fibrosa de la MS(35), sino que los diversos factores antinutrientes (por ejemplo, concanavalina A y canavanina) presentes en las semillas de canavalia limiten el consumo voluntario de este tipo de dietas. Al respecto, se ha sugerido que las lectinas (concanavalina $A$ es una lectina) presentes en $C$. ensiformis y Phaseolus vulgaris reducen la absorción de nutrientes por unirse a la superficie de las células epiteliales del intestino delgado(4). No se encontraron estudios que aborden el posible daño que produce la concanavalina A al epitelio del rumen. Mientras que en un estudio realizado in vitro con canavanina(39) se observó que este aminoácido inhibe el crecimiento de cultivos de la bacteria ácido láctica Lactobacillus arabinosus 17-5 (8014). La magnitud del posible daño de la canavanina a las bacterias presentes en el rumen tendrá que ser abordado en estudios futuros.

Los resultados obtenidos en el consumo de PC, EM, FDN y FDA, así como la GDP, CA y EA sugieren que la aplicación del proceso de fermentación en estado sólido a la dieta con canavalia permitió que los ovinos mostraran mayor eficiencia de crecimiento con relación a la dieta SFC. Se sugiere que esta mayor eficiencia pudiera estar relacionada con una reducción o inhibición de los efectos negativos de los factores antinutrientes presentes en las semillas de $C$. ensiformis. Al respecto, estudios previos(15) muestran que la aplicación de fermentación en estado sólido a harina de semillas crudas de $\mathrm{C}$. ensiformis permite reducir la concentración de canavanina en $12 \%$ con respecto a semillas sin fermentar, 3.7 vs $4.2 \mathrm{~g}$ de canavanina $100 \mathrm{~g} \mathrm{MS}^{-1}$, respectivamente.

La aplicación de fermentación al alimento con canavalia permitió incrementar la eficiencia productiva de los ovinos con relación a una dieta SFC, situación que aumenta las posibilidades de utilización de semillas de canavalia en dietas de finalización para ovinos en regiones tropicales.
In the present study the diets contained a similar ME level, however, lambs with UFWC diet showed greater daily ME intake.

The hot carcass yield was less than $50 \%$ in all treatments, which is consistent with reports in Blackbelly(40) and Pelibuey(41) grazing with feed supplementation; and Pelibuey in confinement(42). However, it was lower to intact $(43,44)$ and castrated(24), Pelibuey fed indoors. Apparently, the carcass yield differences between studies can be attributed to breed, feeding system, diet energy density and slaughter weight.

The primal cuts weight were higher in lambs with UFWC diet. This type of response is attributed to the increased nutrients intake in UFWC, that favors a greater synthesis of muscle tissue. It has been suggested(42) that the higher energy density in the diet promotes a steady increase in muscle tissue up to $44 \mathrm{~kg}$ of weight, after which decreases. In the present study the lambs with the UFWC diet showed a higher and consistent nutrient intake with respect to lambs fed diets that included canavalia, which explains the greater weight of their primal cuts.

The area and greater diameter of $\mathrm{L}$. dorsi muscle were similar in diets UFWC and FC, probably due to the similar FE detected between these two diets. While lambs with UFC diet had lower values in both parameters, as well as a lower $\mathrm{FE}$; the latter is an indicator of the ability of the animal to gain weight depending on feed intake.

With the exception of dry matter, solid state fermentation process did not alter the chemical composition of the diets that included canavalia. However, lambs fed diet fermented with canavalia obtained greater feed efficiency and daily weight gain with respect to those who consumed feed non-fermented with canavalia, which indicates that the application of this process to a feed with raw canavalia meal seeds allows to increase the efficiency of production of finishing lambs. The lambs fed with diet 
Características de la canal

Con excepción del rendimiento de la canal caliente y el diámetro menor del músculo $\mathrm{L}$. dorsi, el resto de las variables estudiadas resultaron afectadas $(\mathrm{P}<0.01)$ por el tipo de dieta (Cuadro 5). Los ovinos que recibieron la dieta SFSC mostraron mayor grasa de cobertura y peso de la canal, así como mayor peso de los cinco cortes primarios con respecto a lo detectado en las dietas FC y SFC. Sin embargo, el área y el diámetro mayor del músculo $\mathrm{L}$. dorsi resultaron similares en los ovinos que fueron alimentados con las dietas SFSC y FC.

El peso de la canal es importante porque representa el mayor valor económico de los productos que se obtienen cuando los ovinos son sacrificados; el peso de la canal en las dietas FC y SFC representó el $73.8 \%$ y $67.3 \%$, respectivamente, del peso de la canal con la dieta SFSC. Esta respuesta puede ser explicada, en parte, por el mayor consumo de EM que mostraron los ovinos con la dieta SFSC. Al respecto, Partida y Martínez(42) mostraron que un incremento en el nivel de energía (de 2.6 a 2.9 Mcal EM kg MS-1) permite obtener una canal más pesada en ovinos Pelibuey. En el presente estudio las dietas contuvieron un nivel similar de EM, sin embargo, los ovinos con la dieta SFSC mostraron mayor consumo de EM.

El rendimiento de la canal caliente fue menor al $50 \%$ en los tres tratamientos evaluados, lo que concuerda con el rendimiento en canal reportado en ovinos Blackbelly(40) y Pelibuey(41) alimentados en pastoreo con complementación alimenticia, y en Pelibuey en estabulación(42). Sin embargo, resultó inferior a lo señalado en ovinos Pelibuey intactos $(43,44)$ y castrados $(24)$ alimentados en estabulación. Al parecer, las diferencias en el rendimiento de la canal entre estudios se pueden atribuir al grupo racial, sistema de alimentación, densidad energética en la dieta y peso al sacrificio.

El peso de los cortes primarios fue mayor en los ovinos con la dieta SFSC respecto a las non-fermented and without canavalia, showed greater nutrient intake that favored better growth efficiency, as well as higher carcass weight. The addition of meal from canavalia seeds in finishing diets of lamb allowed positive changes in growth, weight and carcass composition. However, these changes were smaller with respect to those obtained in lambs fed with a diet without canavalia seeds.

\section{ACKNOWLEDGMENTS}

Thanks to CONACYT for scholarship granted to the first author to perform his graduate studies within the Agro-food Production Program in the tropic, from the Colegio de Posgraduados, Campus Tabasco; and to Dr. José Manuel Piña Gutierrez, owner of El Rodeo farm by the facilities and partial funding of this research.

End of english version

otras dietas; este tipo de respuesta se atribuye al mayor consumo de nutrimentos en la dieta SFSC, condición que favorece una mayor síntesis de tejido muscular. Se ha indicado que una mayor densidad energética promueve un incremento constante de tejido muscular hasta los $44 \mathrm{~kg}$ de peso, después de lo cual disminuye (42). En el presente estudio los ovinos con la dieta SFSC mostraron un consumo superior y constante de nutrimentos con respecto a los ovinos alimentados con las dietas en las que se incluyó canavalia, lo que explica el mayor peso de sus cortes primarios.

El área y diámetro mayor del músculo L. dorsi resultaron similares en los ovinos con las dietas SFSC y FC, probablemente debido a la EA similar que se detectó entre esas dos dietas. Mientras que los ovinos con la dieta SFC presentaron los valores más reducidos en el área y diámetro mayor del músculo L. dorsi, así como una menor 
EA; esta última es indicador de la capacidad del animal para obtener ganancias de peso en función del alimento consumido.

Con excepción de la materia seca, el proceso de fermentación en estado sólido no modificó la composición química de las dietas en las que se incluyó canavalia. No obstante, los ovinos que consumieron la dieta fermentada con canavalia obtuvieron mayor eficiencia alimenticia y ganancia diaria de peso con respecto a los que consumieron alimento sin fermentar con canavalia, lo que indica que la aplicación de este proceso a un alimento con harina de semillas crudas de canavalia permite incrementar la eficiencia de producción de los ovinos en finalización. Los ovinos alimentados con la dieta sin fermentar y sin canavalia, mostraron mayor consumo de nutrimentos; esta circunstancia favoreció que estos ovinos mostraran mayor eficiencia de crecimiento, así como mayor peso de la canal. La incorporación de harina de semillas de canavalia en la dieta de ovinos en finalización permitió cambios positivos en el crecimiento, peso y composición de la canal. Sin embargo, estos cambios fueron de menor magnitud con respecto a los obtenidos en ovinos alimentados con una dieta sin semillas de canavalia.

\section{AGRADECIMIENTOS}

Se agradece al CONACYT la beca otorgada al primer autor para realizar sus estudios de Maestría en Ciencias dentro del programa de Producción Agroalimentaria en el Trópico del Colegio de Postgraduados Campus Tabasco y al Dr. José Manuel Piña Gutiérrez, propietario de la finca El Rodeo por las facilidades otorgadas y el financiamiento parcial de la presente investigación.

\section{LITERATURA CITADA}

1. Dixon RM, Escobar A, Montilla J, Viera J, Carabano J, Mora M, Risso J, et al. Canavalia ensiformis: A legume for the tropics. Recent advances in animal nutrition Conference Proc. Armidal, Australia. 1983:129-140. http:// livestocklibrary.com. au/bitstream/handle/1234/19420/ 83_129.pdf?sequence=1. Accessed 7 Sep, 2014.

2. Parra A, Combellas J, Dixon R. Rumen degradability of some tropical stuffs. Trop Anim Prod 1984; 9: 196-199.

3. León $R$, Angulo I, Jaramillo $M$, Requena $F$, Calabrese $H$. Caracterización química y valor nutricional de granos de leguminosas tropicales para la alimentación de aves. Zootecnia Trop 1993;11:151-170.

4. Ramos G, Frutos P, Giráldez FJ, Mantecón AR. Los compuestos secundarios de las plantas en la nutrición de los herbívoros. Arch Zoot 1998; 47:597-620.

5. Sridhar KR, Seena S. Nutricional and antinutricional significance of four unconventional legumes of the genus Canavalia - A Comparative study. Food Chemistry 2006; 99:267-288.

6. González LA, Hoedtke S, Castro S, Zeyner A. Evaluación de la ensilabilidad in vitro de granos de canavalia (Canvalia ensiformis) y vigna (Vigna unguiculata), solos o mezclados con granos de sorgo (Sorghum bicolor). Rev Cubana Cienc Agric 2012; 46:55-61.

7. Martin PC, Palma JM. Manual para fincas y ranchos ganaderos. Indicadores útiles para su manejo. Tablas tropicales de composición de alimentos. 1ra ed. Colima, México. Agrosystems Editing; 1999.

8. Sivoli L, Michelangeli C, Méndez A. Efecto combinado de la deshidratación en doble tambor y del tostado sobre la energía metabolizable verdadera y factores antinutrientes de harinas de Canavalia ensiformis. Zootecnia Trop 2004; 22:241-249.

9. Würsch P, Del Vedovo S, Koellreutter B. Cell structure and starch nature as key determinants of the digestion rate of starch in legume. Am J Clin Nutr 1986;43:25-29.

10. Tovar J, Björck IM, Asp N-G. Incomplete digestion of legume starches in rats: A study of precooked flours containing retrograded and physically inaccessible starch fraction. J Nutr 1992; 122:1500-1507.

11. Cáceres O, González E, Delgado R. Canavalia ensiformis: leguminosa forrajera promisoria para la agricultura tropical. Pastos y Forrajes 1995; 18: 107-119.

12. Mamani AV. Comportamiento productivo y económico de corderos en engorda con grano de Canavalia ensiformes como harina y pellet [tesis maestría]. Tabasco, México. Universidad Juárez Autónoma de Tabasco; 2013.

13. Valdivié $M$, Elías $A$. Posibilidades del grano de Canavalia ensiformis fermentado con caña (Sacchacanavalia) en pollos de ceba. Rev Cubana Cienc Agric 2006; 40:459-464.

14. Elías A, Aguilera L, Rodríguez Y, Herrera FR. Inclusión de niveles de harina de granos de Canavalia ensiformis en la fermentación de la caña de azúcar en estado sólido (Sacchacanavalia). Rev Cubana Cienc Agric 2009;43:51-54.

15. Carrillo ED. Efecto de la extrusión y fermentación sólida en la concentración de canavanina de semillas de canavalia (Canavalia ensiformis L.) [tesis maestría]. Tabasco, México; Colegio de Postgraduados Campus Tabasco; 2014.

16. Ayuntamiento Constitucional Jalapa. Plan de contingencia municipal. Sistema estatal de protección civil. H. Ayuntamiento Constitucional J alapa, Tabasco, México. 2010. http://www.transparenciajalapa.gob.mx/pdfs/ 
PLAN\% 20MUNI CI PAL\% 20DE\% 20CONTI NGENCI AS\% 20 PROTECCION\%20CIVIL.pdf Consultado 20 Oct, 2014.

17. Cody RP, Smith JK. Applied statistics and the SAS programming language. $3^{\text {th }}$ ed. New York, USA. NorthHolland, Elsevier Science Publishing Co., Inc.; 1991.

18. AOAC. Official Methods of analysis. 16th ed. Arlington, VA, USA: Association of Official Analytical Chemist. 1995.

19. Van Soest PJ, Robertson JB, Lewis BA. Methods for dietary fiber, neutral detergent fiber, and nonstarch polysaccharides in relation to animal nutrition. J Dairy Sci 1991;74:35833597.

20. Ørskov ER, Hovell DeB FD, Mould F. The use of the nylon bag technique for the evaluation of feedstuffs. Trop Anim Prod 1980;5: 195-213.

21. ARC. The nutrient requirements of farm livestock. Technical review. Farnham Royal, UK. Commonwealth Agr Res Bureau. CAB International Press. 1980.

22. Wang Z, Goonewardene LA. The use of MIXED models in the analysis of animal experiments with repeated measures data. Can J Anim Sci 2004;84:1-11.

23. SAS. SAS User's Guide: Statistics (version 9.0 ed.) Cary, N.C. USA: SAS Inst. Inc. 2002.

24. García JA, Núñez-González FA, Rodríguez-Almeida FA, Prieto C, Molina-Domínguez NI. Calidad de la canal y de la carne de borregos Pelibuey castrados. Téc Pecu Méx 1998;36:225232.

25. Partida JA, Braña D. Metodología para la evaluación de la canal ovina. Folleto Técnico No. 9. México. Centro Nacional de Investigación Disciplinaria en Fisiología Animal. Instituto Nacional de Investigaciones Forestales, Agrícolas y Pecuarias. 2011.

26. Martínez AMM, Bores RF, Castellanos AF. Zoometría y predicción de la composición corporal de la borrega Pelibuey. Téc Pecu Méx 1987;25:72-84.

27. Pacheco MA, Rivera J. Utilización del grano de Canavalia ensiformis en dietas para rumiantes. Primera reunión sobre la producción y utilización del grano de Canavalia ensiformis en sistemas pecuarios de Yucatán. Yucatán, México. Universidad Autónoma de Yucatán. 1985.

28. González R. Degradación ruminal de harina de granos de dos variedades de canavalia (Canavalia ensiformis y Canavalia gladiata). Rev Cubana Cienc Agríc 2004;38:53-56.

29. Domínguez-Bello MG, Stewart CS. Effects of feeding Canavalia ensiformis on the rumen flora of sheep, and of the toxic amino acid canavanine on rumen bacteria. System Appl Microbiol 1990;13:388-393.

30. Hughes-J ones M, Encarnación C, Preston TR. Some dietary interactions of sugar cane juice and high protein supplements. Trop Anim Prod 1981;6:271-278.

31. Castellanos AF. Requerimientos alimenticios del borrego Pelibuey. En: Castellanos AF, Arellano C editores. Tecnologías para la producción de ovejas tropicales. Instituto Nacional de Investigaciones, Forestales y Agropecuarias. Organización de las Naciones Unidas para la Agricultura y Alimentación. Yucatán, México. 1989:78-90.

32. Grovum WL. Apetito, sapidez y control del consumo de alimentos. En: Church CD editor. El rumiante, fisiología digestiva y nutrición. 1ra ed. Zaragoza, España: Acribia, SA; 1993:225-241.

33. Young BA. Influencia del estrés ambiental sobre las necesidades nutritivas. En: Church CD editor. El rumiante fisiología digestiva y nutrición. Ira ed. Zaragoza, España: Acribia, SA; 1993:525-538.

34. Domínguez-Bello MG. Detoxification in the rumen. Ann Zootech 1996;45(Suppl):323-327.

35. Dixon RM, Mora M. Particulate matter breakdown and removal from the rumen in sheep given Elephant grass forage and concentrates. Trop Anim Prod 1983;8:254-260.

36. Rebollar-Rebollar S, Hernández-Martínez J, Rojo-Rubio R, González-Razo FJ, Mejía-Hernández P, Cardoso-J iménez D. Óptimos económicos en corderos Pelibuey engordados en corral. Universidad y Ciencia 2008;24:67-73.

37. Oliva J, Vidal A. Utilización del zeranol en borregos Pelibuey en pastoreo y con concentrado energético. Universidad y Ciencia 2001; 17:57-64.

38. Mora-Morelos H, Hinojosa-Cuéllar JA, Oliva-Hernández J. Características de crecimiento postdestete de borregos Pelibuey en pastoreo con suplemento alimenticio. Universidad y Ciencia 2003; 19:105-111.

39. Kihara $\mathrm{H}$, Snell EE. Ethionine, and canavanine inhibitions by thienylalanine, growth: VII. Relation to peptides and bacterial. J Biol Chem 1955;212:83-94.

40. Cantón JG, Velázquez A, Castellanos A. Body composition of pure and crossbred Blackbelly sheep. Small Ruminant Res 1992; 7:61-66.

41. Oliva J, Vidal A. Descripción de la composición corporal en ovinos Pelibuey en pastoreo con complementación alimenticia e implantados con zeranol. Investigación y Posgrado 2013; 3: 9-12.

42. Partida PJA, Martínez RL. Composición corporal de corderos Pelibuey en función de la concentración energética de la dieta y del peso al sacrificio. Vet Méx 2010;41:177-190.

43. Partida PJA, Braña VD, Martínez RL. Desempeño productivo y propiedades de la canal de ovinos Pelibuey y sus cruzas con Suffolk o Dorset. Téc Pecu Méx 2009; 47:313-322.

44. Macías-Cruz U, Álvarez-Valenzuela FD, Rodríguez-García J, Correa-Calderón A, Torrentera-Olivera NG, Molina-Ramírez L, Avendaño-Reyes L. Crecimiento y características de canal en corderos Pelibuey puros y cruzados F1 con razas Dorper y Katahdin en confinamiento. Arch Med Vet 2010;42:147154. 